more intelligent. But Celsus did not want to recognize this fact." ${ }^{157}$ While Origen does not give direct evidence for Africa Proconsularis, he does provide insight into the class makeup of Christianity contemporary to Tertullian and very similar in context. ${ }^{58}$ Fronto, moreover, alleged that Christians "collected from the lowest possible dregs of society the more ignorant fools together with gullible women., ${ }^{59}$ Because Fronto spent much time in Rome, his account may not relate directly to North Africa, but it does align with other sources from neighboring regions and time periods, making its application to North Africa plausible. ${ }^{60}$

\title{
4.4 Tertullian and Class Identity
}

To which class of Roman society was Tertullian born? His skill as a trained orator and his education indicated in his writings seem sufficient to surmise that Tertullian came from or rose to a high level of status or class. Perhaps a more pertinent question, however, and one that can be explored in Tertullian's own works, is "In which class did Tertullian place himself?", or "How did Tertullian construct and depict his own class identity?" Despite the propaganda from nonChristian Romans and new elites, many Christians came from noble ranks in North Africa. The vast majority of Christians, however, were plebs with little or no claim to status as defined by Roman social norms. In order to investigate with which end of the social spectrum Tertullian expressed solidarity the following section will analyze his works De cultu feminarum 1 and 2.

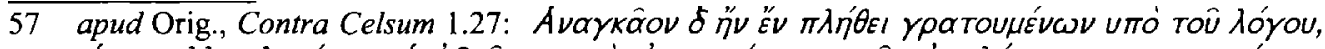

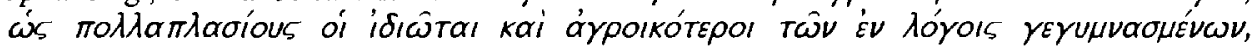

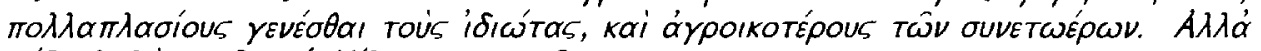

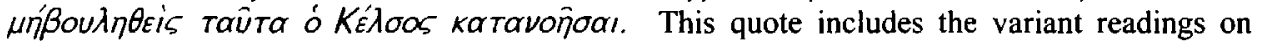
which Chadwick's translation relies.

58 cf. Pliny's declaration of surprise at upper class Christians, Epistula 10.96.4: “...I am convinced that their stubbornness and unshakable obstinacy ought not to go unpunished. There have been others similarly fanatical who are Roman citizens" [Neque enim dubitatam, qualecumque esset quod daterentur, pertinaciam certe et inflexibilem obstinationem debere puniri. Fuerunt alii similis amentiae, quos, quia cives Romani erant, adnotavi in urbem remittendos.] See Braun, "Aux Origines," 192, who contrasts the low class makeup of the Scillitan Christians with the community of Tertullian.

59 apud Minucius Felix, Octauius 8: de ultima faece collectis imperitioribus et mulieribus credulis.

60 For class, esp. lower classes, in Cyprian's flock, see R.H. Weaver, "Wealth and Poverty in the Early Church," Interpretation 41 no 4 (O 1997): 368-381; Frend, "The Early Christian Church in Carthage" in Excavations at Carthage 1976, vol. 3, ed. J.H. Humphrey, (The University of Michigan/Ann Arbor Press, 1977), 33. Similarly, with the Donatists, see Shaw, "African Christianity," 29-30. 


\subsubsection{Class in De cultu feminarum 1}

In the two volume work De cultu feminarum, Tertullian offers no specific historical data by which to date the treatise, which has led to a wide range of scholarly opinions regarding the treatise' sitz im leben. Braun argues that the passage in 1.4.1-2 is a thesis of Tertullian's subject indicating books one and two as parts of a unified work. ${ }^{61}$ Barnes, concurring with the earlier research of $G$. Säflund, believes book two is an independent sermon written ten years prior to book one. ${ }^{62}$ A third possibility, offered by Church, is that Tertullian consolidated two addresses into a single tractate. ${ }^{63}$ While most studies investigate Tertullian's stance towards women as a stylistic criterion for understanding the works and any development of thought between them, the following discussion will take an alternate approach. ${ }^{64}$

Regarding Tertullian's claim in Apologeticum (37.4) that even the noble classes consist of Christians, Barnes observes, "In 197 he gave that boast no specific content, but fifteen years later his open letter to the proconsul Scapula reels off a list of senators, governors and imperial freedmen who are either Christians or sympathetic to Christianity."65 A closer examination of Tertullian's stance on class issues and social organization, undertaken by Dennis E. Groh, contributes valuable insights to recognizing the importance of class, rank and wealth in Tertullian's writings. ${ }^{66}$ Groh finds Tertullian to protest against ambitio and gloria, saying each "has a negative sense and occurs frequently in conjunction with wealth or riches." 7 The following analysis of De cultu feminarum finds two different emphases regarding wealth, thus implying that they are two separate works.

In book one of De cultu feminarum Tertullian concerns himself with wealth in regards to the Christian women (sorores dilectissimae, 1.1.1) of his congregation. ${ }^{68}$ Throughout the work, he writes against outlandish examples of misused riches:

From the smallest caskets is produced an ample patrimony. On a single thread is suspended a million of sesterces. One delicate neck carries about it forests and

61 "Le problème des deux livres du De Cultu feminarum," SP 7 (1966): 133-42; Braun, Deus Christianorum, (Paris: Presses universitaires de France, 1962), 571; in CCSL and Turcan the first tract is entitled De habitu muliebri, based on manuscript evidence.

62 Barnes, Tertullian, 55, and 137, dating De cult. fem. 2 in 196/7, and 1 in 205/6; ref. G. Säflund, De Pallio und die stilistische Entwicklung Tertullians, (Lund: 1955), 106ff. In Tertullian, rev. ed., (1985), 325-6, Barnes reiterates his arguments.

63 "Sex," 92, n. 38; Church does not believe the consolidation to have been from tracts ten years apart as Barnes proposes, but much closer.

64 For a review of feminist readings of Tertullian, see below, section 6.4.1.

65 Barnes, "Pagan Perceptions," 236; ref. Ad Scap. 4.1-4, 5.1-3.

66 "Tertullian's Polemic Against Social Co-optation," Church History 40 (1971): 7-14.

67 Ibid, 9; ref. De pal. 5.5; Ad nat. 2.4.15-16; De mon. 7.5; and $A d$ ux. 2.3.1.

68 Barnes, Tertullian, $117 \mathrm{ff}$., believed this work to be a homily. 
islands. The slender lobes of the ears exhaust a fortune; and the left hand, with its every finger, sports with a several money-bag. Such is the strength of ambition (equal) to bearing on one small body, and that a woman's, the product of so copious wealth. ${ }^{69}$

The temptations of wealth, especially such lavish examples of its misuses, should not be heeded according to Tertullian. He warns the sisters not to fall into the same trap of vanity as Eve (1.1.3). He encourages them to resist the temptations offered by the fallen angels before the days of Noah (1.2.4), and regarding the legend that precious jewels come from dragons (draconum, 1.6.3), Tertullian deduces that women should avoid them as though from that "Serpent" (serpente), the Devil (diaboli). ${ }^{70}$ Book one offers warnings only; Tertullian never rebukes or chastises the sisters for actually succumbing to wealth nor implies that any member of his audience belong to the upper classes.

The only non-biblical example of someone who has fallen into the temptation of wealth is found "at Rome" (Romae, 1.7.2) where provincials' wealth causes noble women (matronis) embarrassment." Tertullian expounds on the "Tyrian" (Tyriis) lack of appreciation for Roman wealth, stating, "Purple with them is more paltry than red ochre" (Vilior est apud illos purpura quam rubrica, 1.8.1). ${ }^{72}$ While on the subject, Tertullian declares that God could have made "sheep to be born with purple and sky-blue fleeces" (purpureas et aerinas oues nasci, 1.8.2) but did not, and therefore any such perversions "are understood to be from the devil" (a diabolo esse intelleguntur, 1.8.2), or more specifically "the devil and his angels" (diabolum et angelos eius, 1.8.3) who have imported "worldly shows" (spectaculorum saecularium, 1.8.4), "frenzies of the racecourse, or the atrocities of the arena, or the turpitudes of the stage" (circi furoribus aut arenae atrocitatibus aut scenae turpitudinibus, 1.8.5), all of which belong solely to those who seek after "worldly glory" (gloriae saeculum, 1.8.6). ${ }^{73}$ Tertullian's sisters, however, never appear within the wealthier classes; instead, he warns them to resist the "Devil" and the temptation to participate with those seeking gloria.

69 1.9.3: De breuissimis loculis patrimonium grande profertur; uno lino decies sestertium inseritur; saltus et insulas tenera cervix circumfert; graciles aurium cutes kalendarium expendunt et sinistra per singulos digitos de saccis singulis ludit. Hae sunt uires ambitionis tantarum usurarum substantiam uno et muliebri corpusculo baiulari.

70 For the "days of Noah" see Gen. 6:1-4 and 1 Enoch 7-8. Marie Turcan, "Être femme selon Tertullien," Vita Latina 119 (September 1990), 15, believes this alludes to Pliny, Naturalis historia.

71 Although Tertullian states he has seen (uidimus) this event, Turcan takes the statement rhetorically.

72 cf. the passage referenced earlier in Tacitus, Annals 3.2, where the soldiers bore the ashes of the fallen Germanicus with fasces proceeding through every colony; he adds that for this occasion "the commons [were] in black, the knights in purple" [atrata plebes, trabeati equites].

73 Given this blatant antagonism toward the Roman imperial presence, a postcolonial read could interpret Tertullian's use of gold and iron (1.5) as subversively analogous to foreign/indigenous or Roman/African. 


\subsubsection{Class in De cultu feminarum 2}

Book two begins with a similar address to Tertullian's "fellow-servants and handmaids" (conseruae et sorores, 2.1.1), but the specification follows that this discourse is "not... of affection, but paving the way for affection in the cause of your salvation" (non... affectationis sed affectioni procurans in causa uestrae salutis). ${ }^{74}$ The different tone between the two volumes stems from the fact that many of the sisters actually have participated in the extravagancies of wealth, whereas Tertullian only warns against such wealth in book one. Tertullian seeks to persuade those who already exhibit "licentious extravagances of dress" (in habitus ...licentia, 2.1.3), "who rub their skin with medicaments, stain their cheeks with rouge, make their eyes prominent with antimony" (quae cutem medicaminibus urgent, genas rubore maculant, oculos fuligine porrigunt, 2.5.2), who own "servants" (serui, 2.5.4), who "turn [the colour of] their hair with saffron" (capillum croco uertere, 2.6.1) and even men who have succumbed to all and more of these excesses (2.8). ${ }^{75}$

As Tertullian develops his argument against, "your riches and elegancies" (diuitiarum uestrarum uel elegantiarum, 2.9.5) rhetoric emerges indicating that the recipients of his rebukes are wealthy converts. He proposes, "When (once) the knowledge of God has put an end to all wish to please by means of voluptuous attraction, all these things are rejected as frivolous, as hostile to modesty" (cum tamen, cognito Deo, adempta placendi uoluntate, per luxuriae occasionem omnia illa ut otiosa ut hostilia pudicitiae recusantur, 2.8.2) ${ }^{76}$ Again, he questions why any would return to pre-conversion habits and asks, "Moreover, what causes have you for appearing in public in excessive grandeur, removed as you are from the occasions which call for such exhibitions?" (Quae autem uobis causa extructius prodeundi cum remotae sitis ab his quae talium indigent?, 2.11.1). ${ }^{77}$ The true motivation, Tertullian adds, is for "seeing and being seen"

74 Turcan prefers the variant affectationi to the genetive of Oehler's text; the confrontational tone, however, in Tertullian remains in either rendering. Therefore, it is suprising in her comments (Tertullien, 21) that she does not elaborate on why she considers book one to be "oratoire et vengeur" but book two to be "humble et suppliant."

75 Comp. 2.5.2 with De paen. 11. Regarding nostri serui (2.5.4), Tertullian's usage seems to be a rhetorical means of saying uestri serui, given the context and overall tone of the treatise; in this paragraph Tertullian compares his audience with "soldiers" (milites) who take gifts from "foes" ( $a b$ hostis), and then returns to his typical usage when he attacks "your schoolings and professions" (uestris disciplinis et professionibus, 2.5.5). Moreover, Harrill, "The Domestic Enemy: A Moral Polarity of Household Slaves in Early Christian Apologies and Martyrdoms," in Early Christian Families, ed. Balch and Osiek, 242-6, illustrates how Tertullian can rhetorically construct "slaves" for the purpose of his argument. Turcan underscores Tertullian's familiarity with military imagery, comparing this reference with De cor. 11.3-4; De spect. 24.4; and De prae. haer. 12.2. The last two, like here in De cult. fem., compare military mutiny with the behaviour under review; the first, however, explicitly declares service to the emperor in the army to be a betrayal by the Christian.

76 Oehler's text for occasionem in keeping with Thelwall's translation; Turcan reads uacationem.

77 The singular causa found by Turcan to be more plausible is a plural, causae, in Oehler. 
(uidere ac uideri) in the various displays of wealth in "public" (publicum) and for the purpose "of inflating glory" (gloria insolescat). The audience should resist "if the requirements of Gentile friendships and of kindly offices call you" ( $s i$ necessitas amicitiarum officiorumque gentilium uos uocat, 2.11.2), and they ought to take pride to "walk in poorer garb" (pauperius incedit, 2.11.3) so as not to appear as prostitutes who imitate "the most honourable women" (honestissimis ... feminis, 2.12.1).

While on the subject of prostitutes in the guise of nobility, Tertullian makes reference to Rome: "That powerful state which presides over the seven mountains and very many waters, has merited from the Lord the appellation of a prostitute" (Illa ciuitas ualida quae super montes septem et plurimas aquas praesidet, cum prostitutae appellationem a domino meruisset, 2.12.2). ${ }^{78} \mathrm{He}$ then expounds, "She sits, to be sure, "in purple, and scarlet, and gold, and precious stone." (Sedet certe in purpura et coccino et auro et lapide pretioso, 2.12.2). Less overt references to Rome and its influences such as "purple and scarlet sheep" (purpureas et coccineas oues, 2.10 .1 ; cf. 2.10 .4 ), and the "public shows" (spectacula, 2.11.1), arise in Tertullian's arguments as well. ${ }^{79}$

From this comparison of the two volumes of De cultu feminarum, several observations can be made regarding Tertullian's discourse on class. The books represent two different occasions when Tertullian speaks about the parameters of a Christian woman's (and man's, 2.8) wardrobe. In book one, he warns the audience against the temptations of wealth and of the pursuits of gloria, but he makes no mention of any Christians who have actually participated in such activities. The second book, however, indicates that Tertullian has witnessed Christians who belong to or have the means of belonging to the upper classes and who display their wealth gratuitously, an option unacceptable to the African theologian. He argues that a convert must reject the immodest and licentious uses

78 ref. Revelations 17:1-10; cf. Adu. Iud. 9.15 and Adu. Marc. 3.13.10.

79 Tertullian also insists, "You ought to hate what ruined your fathers (figuratively, Israel)" [Odisse debetis quod Iudaeos perdidit, 2.13.6]. Instead, they should adorn "the purple of modesty" [purpura pudicitiae, 2.13.7]. Regarding purpureas et coccineas, Turcan only notes that the latter is "un symbole de luxe et de richesse." Other possible subversive references to Rome in De cult. fem. include 2.2 where, like the analogy of iron/gold to Africans/Romans in 1.5, Tertullian's example of Sarah taken from Abraham by the Egyptians could be understood as representing the faithful and the Romans, given Tertullian's concern for women's at risk of rape by persecutors (see below, section 5.4.1). 
of riches and therein reject the upper classes whose lifestyle is entangled in such behaviour. Tertullian, moreover, understands the abusive use of wealth, as typified in the noble classes, attributable to Roman influence. It seems that, to Tertullian, the rejection of upper class identity by the Christian likewise requires a rejection of the Roman system that furthers systemic social stratification among the nationes (2.6.1). 